\title{
Direct Shoot Organogenesis from Lycium chinense Miller Leaf Explants and Assessment of Genetic Stability Using ISSR Markers
}

\author{
Woo-Suk Jung ${ }^{1}$, Ill-Min Chung ${ }^{1}$, Seung-Hyun Kim ${ }^{1}$, Hee-Yeon Chi ${ }^{1}$, Chang Yeon $\mathrm{Yu}^{2}$ and \\ Bimal Kumar Ghimire ${ }^{1, *}$ \\ 1 Department of Crop Science, College of Sanghuh Life Science, Konkuk University, Seoul 05029, Korea; \\ jungw@konkuk.ac.kr (W.-S.J.); imcim@konkuk.ac.kr (I.-M.C.); kshkim@konkuk.ac.kr (S.-H.K.); \\ chi11432@konkuk.ac.kr (H.-Y.C.) \\ 2 Interdisciplinary Program in Smart Science, Kangwon National University, Chuncheon 200-701, Korea; \\ cyyu@kangwon.ac.kr \\ * Correspondence: bimal_g12@yahoo.com; Tel.: +82-010-77141178
}

check for updates

Citation: Jung, W.-S.; Chung, I.-M.; Kim, S.-H.; Chi, H.-Y.; Yu, C.Y.; Ghimire, B.K. Direct Shoot Organogenesis from Lycium chinense Miller Leaf Explants and Assessment of Genetic Stability Using ISSR Markers. Agronomy 2021, 11, 503. https://doi.org/10.3390/agronomy 11030503

Academic Editors: Samir C. Debnath and Shri Mohan Jain

Received: 3 February 2021

Accepted: 2 March 2021

Published: 8 March 2021

Publisher's Note: MDPI stays neutral with regard to jurisdictional claims in published maps and institutional affiliations.

Copyright: (c) 2021 by the authors. Licensee MDPI, Basel, Switzerland. This article is an open access article distributed under the terms and conditions of the Creative Commons Attribution (CC BY) license (https:/ / creativecommons.org/licenses/by/ $4.0 /)$

\begin{abstract}
An efficient in vitro direct shoot regeneration system has been described for Lycium chinense Miller using leaf explants. Influence of various parameters such as growth regulator concentration, explant type, effect of basal salt type, Murashige and Skoog (1962) medium (MS), Schenk and Hildebrandt (1972) medium (SH), Gamborg et al. (1968) medium (B5), and carbon sources (sucrose, maltose, and fructose) on the regenerating shoots has been studied. Micromorphological studies and genetic fidelity of regenerated shoots were assessed and compared with those of the donor plants. Among the different concentrations of plant growth regulator (PGRs) tested, MS supplemented with lower concentration of 6-benzylaminopurine (BAP) $\left(0.5 \mathrm{mgL}^{-1}\right)$ and thidiazuron (TDZ) $\left(0.5 \mathrm{mgL}^{-1}\right)$ increased the frequency of shoot. Comparatively, indole-3-butyric acid (IBA) was more effective in the regeneration and growth of the root system. A higher number of root formation $(6.67 \pm 1.25)$ was observed when the rooting medium comprised half-strength MS salts supplemented with 3\% sucrose. The surviving plantlets were gradually transferred to the greenhouse and natural soil. More than $90 \%$ of the plantlets survived and matured within 85 days. Similarity in the band patterns produced by inter simple sequence repeat (ISSR) primers confirmed the genetic stability and uniformity between the regenerated and donor plants. The present optimized direct shoot regeneration system may be useful for mass propagation and improving the genetic traits in L. chinense.
\end{abstract}

Keywords: Lycium chinense; genetic fidelity; organogenesis; flow cytometry; plant growth regulators

\section{Introduction}

Lycium chinense, belonging to the family Solanaceae, is distributed in northeast Asian countries including China, Korea, Taiwan, and Japan, and has been widely used in traditional medicine [1,2]. L. chinense fruits, traditionally consumed in the form of tea and in alcoholic beverages [3,4], are reported to possess antioxidant, anticancer, and antibacterial properties [5-7]. Previous studies on L. chinense fruits revealed the presence of phytochemicals such as flavonoids [8], phenolic acid [9], xeathanthin, lutein [10], cerebrosides, and lyciumamide [11], potentially responsible for various bioactivities including hypertensive, antipyretic, and hypoglycemic activities [11-13], diabetes, aging, and atherosclerosis $[14,15]$.

Traditionally, L. chinense is propagated using seeds. Low seed germination rate, poor fruit setting, and loss of seed viability limit large-scale propagation of this plant [16]. Moreover, indiscriminate harvesting has resulted in the rapid disappearance of the L. chinense population from its natural habitats and poses a serious threat to its population. In vitro propagation of L. chinense using different explants such as the induction of shoots from callus [17] and hypocotyl [18] has been attempted. 
Regeneration methods developed for L. chinense in previous studies are less consistent, with low regeneration rates mostly when induced from callus. The shoot regenerated from callus possesses higher potential of somaclonal variations $[19,20]$. However, assessment of different factors such as MS, sugar, shoot, and root growth medium, and genetic fidelity of the regenerated plants has not been performed earlier in L. chinense. Therefore, the objectives of the present study were to optimize the regeneration system of L. chinense and assess the other factors related to the propagation/regeneration of L. chinense.

In vitro propagation using vegetative explants is an important technique for rapid production and improvement in plant breeding. However, the major problem associated with in vitro propagation is the possibility of somaclonal variations within the subclones due to genetic changes that occur as a result of prolonged cultural stress [19,21]. In particular, generation of shoots from callus is time consuming, and may lead to somaclonal variations and the loss of regeneration potential [22]. In contrast, direct shoot regeneration is considered the best alternative approach because it possesses greater regeneration potency, with multiple shoots being produced within a short span of time and minimal genetic fidelity [22,23]. An efficient regeneration system with direct shoot organogenesis is a prerequisite for the improvement of genetic traits in plants through genetic transformation and large-scale production of plantlets in breeding programs. Moreover, the seedlings developed from seeds are mostly heterogenous and might not retain suitable parental traits [24]. They are genetically stable, are more identical to parental lines, and provide high yielding clones [25].

Genetic variation among in vitro regenerated plants may occur at ploidy levels [26] and cause DNA methylation changes $[27,28]$. Genetic fidelity assessment is required for the true-to-type production of regenerants. Application of molecular markers in assessing genetic fidelity has several advantages as it is not influenced by environmental factors, and is a quick, robust, efficient, and cost-effective process [29]. Several molecular markers including random amplified polymorphic DNA (RAPD), amplified fragment length polymorphism (AFLP), restriction fragment length polymorphisms (RFLP), simple sequence repeats (SSR), and inter simple sequence repeat (ISSR) have been used to assess the genetic stability of regenerated shoots. Of these, ISSR has received considerable attention as it is extensively used for detecting genetic fidelity in in vitro regenerated plants and for studying genetic relationships within the species [30]. However, the establishment of direct shoot regeneration and analysis of genetic variabilities using molecular markers in L. chinense has not been reported.

Therefore, in the present study, we developed an efficient system for direct shoot regeneration, and subsequent SSR analyses of regenerated shoots were accomplished. In addition, to obtain an efficient regeneration system, different parameters that influence the regeneration of shoots from leaf explants such as plant growth regulators (PGRs), basal medium, and carbon source were considered. Histological analysis of regenerating shoots and microfoliar studies on stomatal and trichome structure were conducted for comparison with donor plants. The stability of regenerated plantlets was determined using ISSR primers to detect any genetic fidelity in the regenerated plant.

\section{Materials and Methods}

\subsection{Seed Germination and Explant Preparation}

Seeds of L. chinense were collected from the Bioherb Research Institute, Kangwon National University, South Korea. Initially, seeds were agitated in 70\% ethanol (Daejung Chemical and Metal Co. Ltd., Gyenggi-Do, South Korea) for $5 \mathrm{~min}$ and surface sterilized in 5.0\% sodium hypochlorite solution (Yakuri Pure Chemicals Co. Ltd., Kyoto, Japan) supplemented with 0.02\% Tween 20 (Sigma-Aldrich Co., St. Louis, MO, USA) for $30 \mathrm{~min}$. Subsequently, the seeds were rinsed with sterile distilled water prior to inoculating aseptically in Petri dishes containing Murashige and Skoog (Duchefa Biochemie, BH Hallem, The Netherlands) medium supplemented with 3\% sucrose and 0.8\% agar (Duchefa Bio- 
chemie, $\mathrm{BH}$ Hallem, The Netherlands) at $28^{\circ} \mathrm{C}$, under a 16-h photoperiod and fluorescent illumination $\left(36 \mu \mathrm{mol} \mathrm{m}{ }^{-1} \mathrm{~s}^{-1}\right)$.

\subsection{Culture Conditions and Regeneration of Shoots}

Leaves from 4-week-old in vitro grown donor plants were excised and cut into segments at the midrib region. All the leaf segments were transferred to Petri dishes containing different basal media such as SH, MS, or B5 (Duchefa Biochemie, BH Hallem, the Netherlands), carbon sources (sucrose, maltose, or fructose), and PGRs including BAP, TDZ, and NAA (Sigma-Aldrich Co., St. Louis, MO, USA). Cultured explants were transferred to a culture room under the same conditions as mentioned before.

\subsection{Influence of Carbon Source and Basal Medium on Shoot Regeneration}

The influence of different basal media, viz., MS [31], B5 [32], and SH [33] on shoot regeneration of $L$. chinense was assessed. Each basal medium was supplemented with $3 \%(w / v)$ sucrose, $0.8 \%(w / v)$ agar, and $0.5 \mathrm{mg} / \mathrm{L}$ TDZ. In addition, different types of carbohydrate sources such as sucrose $(3 \%)$, maltose $(3 \%)$, and fructose $(3 \%)$ were also tested for adventitious shoot regeneration. The $\mathrm{pH}$ of all the regenerating media was adjusted to 5.8, and were sterilized by autoclaving at $121{ }^{\circ} \mathrm{C}$ and $125 \mathrm{kPa}$ for $20 \mathrm{~min}$. The sterilized media were dispensed into sterile Petri dishes, and leaf segments were transferred to the Petri dishes. After 30 days, the percentage of shoot induction, number of shoots per shoot, and shoot length were recorded.

\subsection{Rooting and Plant Acclimatization}

For rooting, healthy and elongated shoots $(2.0-3.0 \mathrm{~cm})$ were transferred to rooting medium consisting of MS supplemented with indole acetic acid (IAA), indole-3-butyric acid (IBA), or $\alpha$-naphthaleneacetic acid (NAA) at $1 \mathrm{mg} / \mathrm{mL}, 30 \mathrm{~g} / \mathrm{L}$ sucrose, and $8 \mathrm{~g} / \mathrm{L}$ agar. The cultures were transferred to a growth chamber and maintained at $25-27^{\circ} \mathrm{C}$, at a light intensity of $36 \mu \mathrm{mol} \cdot \mathrm{m}^{-2} \cdot \mathrm{s}^{-1}$ under a 16-h photoperiod. Each experiment was conducted in triplicate, with ten shoots per replicate. The average number of roots per explant and root length were recorded after four weeks of incubation. For in vivo plantlet acclimatization, healthy rooted regenerated plantlets were removed from the rooting medium, and washed in tap water to remove any attached medium. The plantlets were then transplanted in plastic pots (100 $\mathrm{mm} \times 85 \mathrm{~mm}$ diameter) containing a mixture of autoclaved vermiculite and perlite at 1:1. The pots were irrigated with half-strength MS salt solution, and covered with a perforated polythene bag to maintain high humidity for a week. All the pots were placed in a culture room for a week, under a 16-h photoperiod, at a light intensity of $30 \mu \mathrm{mol} \cdot \mathrm{m}^{-2} \cdot \mathrm{s}^{-1}$ provided by cool white fluorescent tubes. Subsequently, the humidity of the sealed pots was reduced by punching more holes in the covered polythenes. The pots containing acclimatized shoots were placed in a greenhouse at $25-28{ }^{\circ} \mathrm{C}$ for one month. The polythene bags were gradually removed. The surviving regenerated plantlets were acclimatized in greenhouse conditions and then transplanted to the field. Percentage survival of regenerated plantlets was assessed six weeks after transplanting to the field.

\subsection{Micromorphological Studies}

\subsubsection{Venation Pattern and Trichome Density}

To study the venation pattern, healthy and fresh leaves of generated and donor plants were excised and fixed in formalin-acetic acid-ethyl alcohol (1:1:3). Fixed leaves were transferred into $70 \%$ ethyl alcohol $(v / v)$ for $12 \mathrm{~h}$, and bleached with $5 \% \mathrm{NaOH}$ for $24 \mathrm{~h}$. After rinsing three times, the bleached leaves were stained with $1 \%$ safranin $(v / v)$ for $5 \mathrm{~min}$. Stained samples were examined under a microscope (BX 50, Olympus, Japan) and photographed with an Olympus C4040 Zoom digital camera (Olympus, Japan) to study the venation pattern and vein-islet termination density. 


\subsubsection{Histological Study of Regenerated Plants}

To study the developmental stages of the regenerating plants, samples were periodically collected from the in vitro cultures and fixed in FAA solution (free fatty acid). The regenerating primordial tissues from samples at different stages were dehydrated in a graded butanol series (50-99\%) and embedded in paraffin blocks. The embedded samples were sectioned into $6 \mu \mathrm{m}$ slices using a microtome (Uchida Yoko Co. Ltd., Tokyo, Japan). The sections were placed on the slides, dewaxed, and stained with hematoxylin solution for $5 \mathrm{~min}$. All the stained sections were observed under a light microscope (BX 50, Olympus, Japan) and photographed using an Olympus C4040 Zoom camera (Olympus, Japan).

\subsubsection{Size and Density of Stomata}

Healthy leaves were excised from the regenerated and donor plants between 10:00 and 12:00 a.m., and immediately fixed in acetic acid:ethanol (1:3) for a day. The leaf epidermis was carefully peeled off and stained with a drop of 1:2 iodine:potassium iodide solution for $10 \mathrm{~min}$ ( $1 \mathrm{~g}$ iodine and $2 \mathrm{~g}$ potassium iodide, dissolved in $100 \mathrm{~mL}$ distilled water) following the method described by Ghimire et al. [34]. The number and size of stomata were recorded for the donor plants and regenerated plantlets using an ocular micrometer. Clear and informative stomatal images were acquired using a 3CCD camera (Niko DS-U2/L2 USB) connected to a computer running NIS-Elements F3.00 software (Niko Corp., Indianapolis, IN, USA).

\subsection{Assessment of Ploidy Level in Regenerants}

The ploidy level of regenerated plants was determined and compared to that of donor plants by following the methods described by Ghimire et al. [35]. Fifteen regenerated plants grown in greenhouse conditions were randomly selected for the flow cytometry study. Lycopersicon esculentum cv. Stupicke ( $2 \mathrm{C}=1.96 \mathrm{pg}$ DNA) served as an internal standard. Initially, fresh young leaves of regenerated and donor plants $\left(50 \mathrm{~mm}^{2}\right)$ were chopped using a sharp razor in a Petri dish $(96 \mathrm{~mm})$, with nuclear extraction buffer (A) solution (Partec High Resolution DNA Kit, Munster, Germany). The solution was passed through a $45 \mu \mathrm{m}$ nylon mesh membrane (Partec Celltrics, Munster, Germany) into a $5 \mathrm{~mL}$ cytometry tube to separate the debris. The solution was centrifuged for $5 \mathrm{~min}$ at $180 \times g$ at room temperature $25^{\circ} \mathrm{C}$ ). Subsequently, $1 \mathrm{~mL}$ of propidium iodide (Pi) was added into the filter and incubated for $30 \mathrm{~min}$ at room temperature $\left(25^{\circ} \mathrm{C}\right)$. The ploidy level of the regenerated plants was measured by comparing the relative fluorescence intensity using a Partec CA-II flow cytometer (Munster, Germany).

\subsection{Inter Simple Sequence Repeat (ISSR) Analysis}

Young leaves each from regenerated and mother plants were collected for DNA extraction. DNA of individual accessions were extracted by following the standard cetyl trimethylammonium bromide (CTAB) method [36]. A total of ten ISSR primers, obtained from the Bioherb Research Institute, Kangwon National University, South Korea, were used for studying the genetic stability of regenerated plants. Amplification of genomic DNA was performed using $20 \mu \mathrm{L}$ reaction volume comprising of $1.5 \mu \mathrm{L} 10 \times$ buffer (Intron Biotechnology, Sangnam, South Korea), 1.0 $\mu \mathrm{L}$ dNTP (Intron Biotechnology, Sangnam, South Korea), $1 \mu \mathrm{L}$ of each primers, and $0.15 \mu \mathrm{L}$ Tag DNA polymerase (Intron Biotechnology, Sangnam, South Korea) and 50 ng genomic DNA of samples. The amplified PCR products were loaded into a $1 \%$ agarose gel in $0.5 \times$ TBE buffer, and electrophoretically separated for $25 \mathrm{~min}$ at $25 \mathrm{~V}$. The amplified bands were observed and photographed under a gel documentation system (BIO-RAD Laboratories, Hercules, CA, USA), and an IKB DNA ladder (Invitrogen, Waltham, MA, USA) was used to estimate the number and sizes of the obtained bands. 


\subsection{Statistical Analysis}

All experiments were performed by making at least three replicates. The numerical data $(x)$ for the average number of shoots per explants, shoot height, root length were transformed by $\log 10(\mathrm{x}+1)$. The data expressed as percentage (shoot regeneration) were transformed by Freeman-Tukey transformation. The transformed data were used for statistical analysis. Real quantitative data obtained from the experiments are presented in Tables 1-6. Alphabet letters indicate that each homogenous group were based on transformed data.

Table 1. Influence of different plant growth regulators on direct adventitious shoot regeneration from leaves of L. chinense after six weeks of culture.

\begin{tabular}{|c|c|c|c|c|c|c|c|}
\hline \multicolumn{3}{|c|}{ Plant Growth Regulator (mg/L) } & \multirow{2}{*}{$\begin{array}{l}\text { No. of Shoots } \\
\text { Per Explant }\end{array}$} & \multirow{2}{*}{$\begin{array}{l}\text { Shoot Height } \\
(\mathrm{mm})\end{array}$} & \multirow{2}{*}{$\begin{array}{l}\text { No. of Roots } \\
\text { Per Explant }\end{array}$} & \multirow{2}{*}{$\begin{array}{c}\text { Shoot } \\
\text { Regeneration } \\
(\%)\end{array}$} & \multirow{2}{*}{$\begin{array}{l}\text { Root Length } \\
(\mathrm{mm})\end{array}$} \\
\hline NAA & BA & TDZ & & & & & \\
\hline 0.0 & 0.0 & & $0.00^{\mathrm{a}}$ & $0.00^{a}$ & $0.00^{a}$ & $0.00^{\mathrm{a}}$ & $0.00^{a}$ \\
\hline 0.0 & 0.5 & & $7.50 \pm 0.90^{\mathrm{e}}$ & $12.30 \pm 1.00^{\mathrm{e}}$ & $0.00^{a}$ & $70.10 \pm 1.10^{\mathrm{f}}$ & $0.00^{a}$ \\
\hline 0.1 & 0.1 & & $0.00^{\mathrm{a}}$ & $0.00^{\mathrm{a}}$ & $0.00^{\mathrm{a}}$ & $0.00^{\mathrm{a}}$ & $0.00^{\mathrm{a}}$ \\
\hline 0.1 & 1.0 & & $3.01 \pm 0.52^{b, c}$ & $1.60 \pm 0.20^{b}$ & $0.00^{\mathrm{a}}$ & $36.71 \pm 2.50^{\mathrm{e}}$ & $0.00^{a}$ \\
\hline 0.1 & 2.0 & & $3.80 \pm 0.10^{c, d}$ & $3.77 \pm 0.10^{\mathrm{d}}$ & $0.00^{\mathrm{a}}$ & $20.10 \pm 1.00^{b}$ & $0.00^{\mathrm{a}}$ \\
\hline 1.0 & 0.1 & & $0.00^{\mathrm{a}}$ & $0.00^{\mathrm{a}}$ & $2.01 \pm 0.50^{\mathrm{c}}$ & $0.00^{\mathrm{a}}$ & $3.43 \pm 0.20^{c}$ \\
\hline 1.0 & 1.0 & & $0.00^{\mathrm{a}}$ & $0.00^{\mathrm{a}}$ & $0.00^{\mathrm{a}}$ & $0.00^{a}$ & $0.00^{\mathrm{a}}$ \\
\hline 1.0 & 2.0 & & $0.00^{\mathrm{a}}$ & $0.00^{\mathrm{a}}$ & $4.77 \pm 0.60^{\mathrm{d}}$ & $0.00^{\mathrm{a}}$ & $5.70 \pm 0.05^{\mathrm{d}}$ \\
\hline 2.0 & 0.1 & & $0.00^{\mathrm{a}}$ & $0.00^{\mathrm{a}}$ & $0.00^{a}$ & $0.00^{\mathrm{a}}$ & $0.00^{\mathrm{a}}$ \\
\hline 2.0 & 1.0 & & $0.00^{\mathrm{a}}$ & $0.00^{\mathrm{a}}$ & $0.00^{\mathrm{a}}$ & $0.00^{\mathrm{a}}$ & $0.00^{\mathrm{a}}$ \\
\hline 2.0 & 2.0 & & $3.10 \pm 0.50^{b-d}$ & $1.10 \pm 0.10^{b}$ & $3.34 \pm 0.20^{c}$ & $20.31 \pm 1.00^{d}$ & $1.77 \pm 0.10^{b}$ \\
\hline 0.0 & & 0.5 & $8.50 \pm 0.90^{\mathrm{e}}$ & $13.30 \pm 1.00^{f}$ & $0.00^{\mathrm{a}}$ & $80.10 \pm 1.50^{g}$ & $0.00^{\mathrm{a}}$ \\
\hline 0.1 & & 0.1 & $0.00^{\mathrm{a}}$ & $0.00^{\mathrm{a}}$ & $0.00^{\mathrm{a}}$ & $0.00^{\mathrm{a}}$ & $0.00^{\mathrm{a}}$ \\
\hline 0.1 & & 1.0 & $4.38 \pm 0.30^{\mathrm{d}}$ & $2.67 \pm 0.10^{c}$ & $0.00^{\mathrm{a}}$ & $30.10 \pm 2.50^{d}$ & $0.00^{\mathrm{a}}$ \\
\hline 0.1 & & 2.0 & $2.10 \pm 0.10^{b}$ & $2.60 \pm 0.40^{c}$ & $0.00^{\mathrm{a}}$ & $18.10 \pm 0.60^{b}$ & $0.00^{\mathrm{a}}$ \\
\hline
\end{tabular}

The data represent the mean \pm SD of three independent experiments. Within columns, means followed by the same letter did not differ significantly according to Tukey's honestly significant difference test $(p<0.05)$.

Table 2. Influence of basal salt types on shoot regeneration of L. chinense after six weeks of culture.

\begin{tabular}{ccc}
\hline Medium & No. of Shoot Per Explant & Average Shoot Length (mm) \\
\hline MS & $8.67 \pm 0.94^{\mathrm{b}}$ & $23.33 \pm 1.05^{\mathrm{b}}$ \\
B5 & $0^{\mathrm{a}}$ & $0^{\mathrm{a}}$ \\
SH & $0^{\mathrm{a}}$ & $0^{\mathrm{a}}$
\end{tabular}

Each value represents the mean \pm SD of three independent experiments with 30 explants per treatment. Within columns, means followed by the same letter did not differ significantly according to Tukey's honestly significant difference test $(p<0.05)$. The culture medium was supplemented with $3 \%$ sucrose and $0.5 \mathrm{mg} / \mathrm{L} \mathrm{TDZ}$.

Table 3. Influence of carbohydrate source on shoot regeneration of L. chinense after six weeks of culture.

\begin{tabular}{ccc}
\hline $\begin{array}{c}\text { Carbohydrate } \\
\text { Source }\end{array}$ & No. of Shoot Per Explant & Average Shoot Length (mm) \\
\hline Sucrose (3\%) & $8.33 \pm 1.10^{\mathrm{c}}$ & $22.67 \pm 1.69^{\mathrm{c}}$ \\
Fructose (3\%) & $1.33 \pm 0.47^{\mathrm{a}}$ & $1.67 \pm 0.40^{\mathrm{a}}$ \\
Maltose (3\%) & $5.00 \pm 0.82^{\mathrm{b}}$ & $16.67 \pm 2.49^{\mathrm{b}}$ \\
\hline
\end{tabular}

Each value represents the mean \pm SD of three independent experiments with 30 explants per treatment. Within columns, means followed by the same letter did not differ significantly according to Tukey's honestly significant difference test $(p<0.05)$. The culture medium was supplemented with MS salt and $0.5 \mathrm{mg} / \mathrm{L}$ TDZ. 
Table 4. Influence of different plant growth regulator concentrations on rooting of L. chinense shoots after six weeks of culture.

\begin{tabular}{ccccc}
\hline Medium & $\begin{array}{c}\text { Average Root } \\
\text { no. Per Explant }\end{array}$ & $\begin{array}{c}\text { Average Root } \\
\text { Length }(\mathbf{m m})\end{array}$ & $\begin{array}{c}\text { Average Shoot } \\
\text { Length }(\mathbf{m m})\end{array}$ & Callus \\
\hline MS & $4.11 \pm 0.50^{\mathrm{a}, \mathrm{b}}$ & $8.89 \pm 1.10^{\mathrm{b}, \mathrm{c}}$ & $8.00 \pm 0.80^{\mathrm{b}, \mathrm{c}}$ & No \\
1/2MS & $7.22 \pm 1.10^{\mathrm{cd}}$ & $59.67 \pm 2.10^{\mathrm{f}}$ & $51.00 \pm 3.10^{\mathrm{e}}$ & No \\
1/3MS & $2.78 \pm 1.05^{\mathrm{a}}$ & $14.11 \pm 1.60^{\mathrm{e}}$ & $7.33 \pm 1.05^{\mathrm{b}, \mathrm{c}}$ & No \\
1/4MS & $5.72 \pm 1.00^{\mathrm{b}, \mathrm{c}}$ & $6.68 \pm 1.10^{\mathrm{a}}$ & $5.00 \pm 1.60^{\mathrm{a}}$ & No \\
MS + 1 mg/L IBA & $8.44 \pm 0.50^{\mathrm{d}}$ & $10.67 \pm 1.60^{\mathrm{c}}$ & $6.67 \pm 1.00^{\mathrm{b}}$ & Yes \\
MS + 1 mg/L IAA & $13.33 \pm 0.15^{\mathrm{e}}$ & $8.67 \pm 2.00^{\mathrm{b}}$ & $13.50 \pm 1.05^{\mathrm{d}}$ & No \\
MS + 1 mg/L NAA & $2.33 \pm 0.40^{\mathrm{a}}$ & $14.00 \pm 1.00^{\mathrm{e}}$ & $8.83 \pm 1.00^{\mathrm{c}}$ & Yes \\
\hline
\end{tabular}

Each value represents the mean \pm SD of three independent experiments with 30 explants per treatment. Within columns, means followed by the same letter did not differ significantly according to Tukey's honestly significant difference test $(p<0.05)$.

Table 5. Structure and density of stomatal apparatus of regenerated and field grown (donor) plants.

\begin{tabular}{cccc}
\hline Plants & Length $(\mu \mathrm{m})$ & Breadth $(\mu \mathrm{m})$ & Total Number \\
\hline Field grown plants & $15.00 \pm 0.82^{\mathrm{b}}$ & $10.00 \pm 0.83^{\mathrm{b}}$ & $35.00 \pm 1.56^{\mathrm{b}}$ \\
Regenerated plant & $14.00 \pm 1.05^{\mathrm{a}}$ & $9.00 \pm 0.47^{\mathrm{a}}$ & $33.33 \pm 2.49^{\mathrm{a}}$
\end{tabular}

Each value represents the mean \pm standard deviation of three independent experiments with 30 explants per treatment. Within columns, means followed by the same letter did not differ significantly according to Tukey's honestly significant difference test $(p<0.05)$.

Table 6. Density of trichome and vein-islet termination density from regenerated and field grown (donor) plants.

\begin{tabular}{ccc}
\hline Plants & Density of Trichome & Density of Islet Termination * \\
\hline Field grown plants & $24.00 \pm 1.56^{\mathrm{a}}$ & $45.00 \pm 2.90^{\mathrm{b}}$ \\
Regenerated plant & $25.00 \pm 1.74^{\mathrm{b}}$ & $43.33 \pm 2.40^{\mathrm{a}}$ \\
\hline
\end{tabular}

Each value represents the mean \pm standard deviation of three independent experiments with 30 explants per treatment. Within columns, means followed by the same letter did not differ significantly according to Tukey's honestly significant difference test $(p<0.05)$. ${ }^{*}$ Stomata, islet termination, and trichome density counted as average number of stomata, islet termination, or trichomes per square millimeter $\times$ area of the leaf in square millimeter.

\section{Results}

\subsection{Effect of Plant Growth Regulators (PGRs) on Direct Shoot Regeneration}

Direct shoot regeneration of $L$. chinense was observed in the leaves of in vitro grown plants. The excised leaf sections were treated with a combination of auxin (NAA) and cytokinins (BAP, TDZ). The morphogenetic variation shown by the leaf sections inoculated in the individual treatment is shown in Table 1. Plant regeneration via direct shoot organogenesis was achieved in leaf explants of $L$. chinense. The adventitious shoots were directly produced from the periolar and basal parts of leaf explants cultured in MS medium supplemented with various concentrations of PGRs. The concentration of PGRs significantly influenced the shoot regeneration frequency. Visible changes occurred in the samples, with a small enlargement at the cut end of the basal part of leaf explants within the first week of transfer into the shoot induction medium (Figure 1A,B). After 3-4 weeks of explant culture, small knob-like protuberances were observed at the cut ends of incubated explants. The regenerating shoots completely covered the explants (Figure 1C). Among the different concentration of PGRs tested, MS supplemented with lower concentration of BAP $(0.5 \mathrm{mg} / \mathrm{L})$ and TDZ $(0.5 \mathrm{mg} / \mathrm{L})$ increased the frequency of shoots. In contrast, MS medium supplemented with a higher concentration of BAP and TDZ produced fewer shoots. Explants inoculated in MS medium in the absence of PGRs did not show shoot organogenesis, and ultimately became necrotic after 10 days of culture. With the increase in BAP and TDZ concentrations from 0.5 to $2.0 \mathrm{mg} / \mathrm{L}$, the frequency of shoot regeneration decreased. 

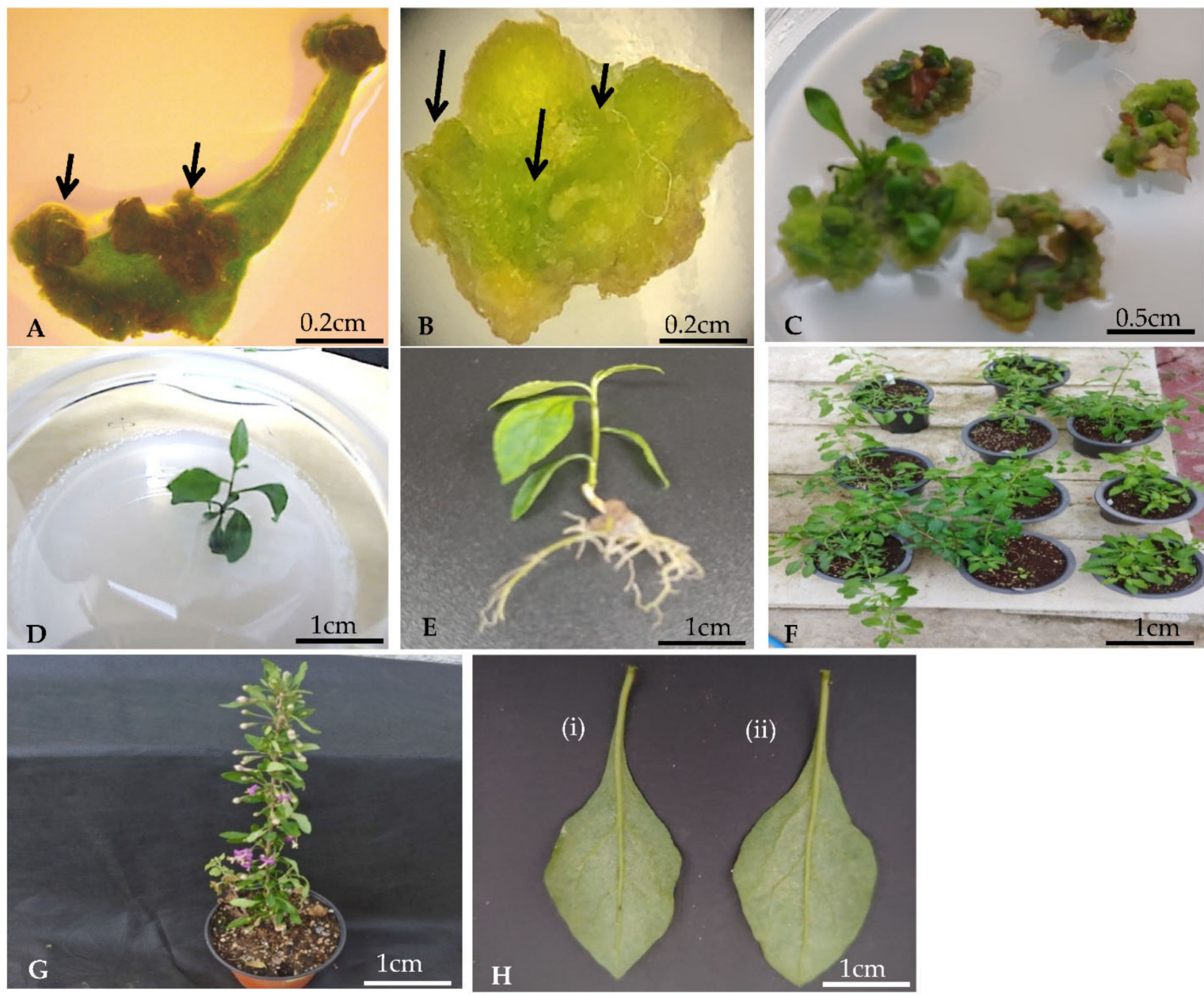

Figure 1. In vitro regeneration of Lycium chinense via direct shoot organogenesis. (A) Shoot bud initiation (arrows head) from the basal end of petiole explants after 2 weeks of culture on Murashige and Skoog (MS) medium supplemented with $0.5 \mathrm{mg} / \mathrm{L}$ thidiazuron (TDZ) (bar $=0.1 \mathrm{~cm}$ ). (B) Regeneration of multiple shoots from leaf explants after three weeks of culture on MS supplemented with $0.5 \mathrm{mg} / \mathrm{L} \mathrm{TDZ}(\mathrm{bar}=1 \mathrm{~cm}) .(\mathrm{C})$ Well-developed elongated shoots after eight weeks of culture on MS supplemented with $0.5 \mathrm{mg} / \mathrm{L} \mathrm{TDZ}$ (scale bar $=0.5 \mathrm{~cm}$ ). (D) Rooting of regenerated shoots after four weeks of culture on MS supplemented with $1 \mathrm{mg} / \mathrm{L}$ indole-3-butyric acid (IBA) (bar $=1 \mathrm{~cm}$ ). (E) A plantlet with a well-developed root system $(\mathrm{bar}=1 \mathrm{~cm})$. (F) Acclimatized plantlets growing in a greenhouse in pots containing a 3:1 mixture of sterilized vermiculite and perlite. (G) Flowering of acclimatized L. chinense plants in greenhouse conditions. (H) Leaf of (i) in vitro regenerated plant, (ii) leaf of donor plant.

\subsection{Influence of Basal Medium and Carbohydrate Source on Organogenesis}

The effect of basal salt types on the frequency of shoot regeneration depicted in Table 2. In the present study, a higher frequency of shoot regeneration was observed on MS (8.67 \pm 0.94 number of shoot per explant) than on B5 or SH. We determined the highest frequency of shoot induction ( $8.33 \pm 1.25$ number of shoot per explant) when leaf explants were cultured on MS supplemented with $3 \%$ sucrose (Table 3). In comparison, leaf explants cultured on MS supplemented with 3\% fructose and 3\% maltose showed significantly lower frequencies of shoot regeneration.

\subsection{Effect of PGRs and Basal Salt Concentrations on Root Regeneration}

Healthy young regenerated shoots were excised from the explants and transferred into the root induction medium supplemented with various concentrations of MS salt and PGRs (Figure 1C). Root emerged from the basal (cut end) region of adventitious shoots within eight days of transfer to the rooting medium (Figure 1D). Root formation was observed 
in all the PGR treatments and MS salt concentrations, but the frequency of root formation varied (Table 4). Comparatively, IBA was more effective in the regeneration and growth of the root system. Addition of $1 \mathrm{mg} / \mathrm{L}$ IAA in the root induction medium generated a higher number of roots, with an average of $13.33 \pm 0.15$ roots/explant. In contrast, addition of $1 \mathrm{mg} / \mathrm{L}$ NAA in the root induction medium resulted in a reduced number of roots $(2.33 \pm 0.40)$ and basal callusing. Similarly, inclusion of IBA in the rooting medium increased the total number of roots $(8.44 \pm 0.50)$ and the root length $(10.67 \pm 1.60 \mathrm{~mm})$.

Varying basal salt concentration in the rooting medium influenced adventitious root formation (Table 4). Increased root formation (7.22 \pm 1.10 roots per explant) was observed when the rooting medium comprised half-strength MS salts supplemented with $3 \%$ sucrose. Comparatively, higher shoot elongation was also achieved $(51.00 \pm 3.10 \mathrm{~mm})$ in halfstrength MS salts supplemented with $3 \%$ sucrose. Further decrease in MS salt concentration resulted in a lower number of roots per explant and shorter shoots. Root induction frequency was reduced in root induction medium supplemented with 1/3MS and fullstrength MS salts.

\subsection{Acclimatization}

Healthy plantlets $(10-14 \mathrm{~cm})$ with well-developed root systems (6-9 roots) (Figure 1E) were transplanted into pots containing vermiculite and perlite in a ratio of 1:1. Each pot was covered with a polyethylene for a week to maintain the relative humidity $(80-90 \%)$, and transferred to the growth chamber for two weeks. The surviving plantlets were gradually transferred to the greenhouse and natural soil (Figure 1F). Over $90 \%$ of the plantlets survived, and matured within 85 days. The acclimatized plants showed normal growth, and developed, matured, and flowered normally (Figure 1G), with no variations from seed-derived mother plants with respect to leaf morphology (Figure 1H, i \& ii).

\subsection{Histological Analysis of Regenerated Shoot}

Histological studies of the regenerated shoots revealed the first visible change in the epidermal region along the cut edges of explants. Initially, the regenerated shoots appeared dome-shaped, with distinct leafy primordia connected to the leafy mother explants (Figure 2A,B). Microscopic analysis revealed a slight protrusion of a globular structure from the epidermal cells of explants two days after culture. The number of globular structures varied among the explants used. The globular structure was mainly composed of dense cells, which subsequently developed into shoot primordia (Figure 2C). Numerous shoot primordia were often observed at the midrib and basal region of the leaves. The shoot primordia were not connected to the vascular bundles of the explants (Figure 2D). Each globular primordium was covered by an extracellular matrix that further developed into shoot primordia.

\subsection{Micromorphological Studies}

\subsubsection{Stomata and Veinlets}

The stomatal apparatus was observed on the abaxial surface of leaves in both regenerated and donor plants. The number of stomata was recorded on the adaxial surface of leaves. The size and density of stomata in the regenerated plants varied slightly with the donor plants (Figure 3A,B). The total number of stomata in the leaves of regenerated plants was less $\left(33.33 \pm 2.49 / \mathrm{mm}^{2}\right)$ than the donor plants $\left(35.00 \pm 1.56 / \mathrm{mm}^{2}\right)$, but the difference was not significant (Table 5). The outer shape of guard cells in both regenerated and donor plants was elliptical, and the stomata were prolonged. 

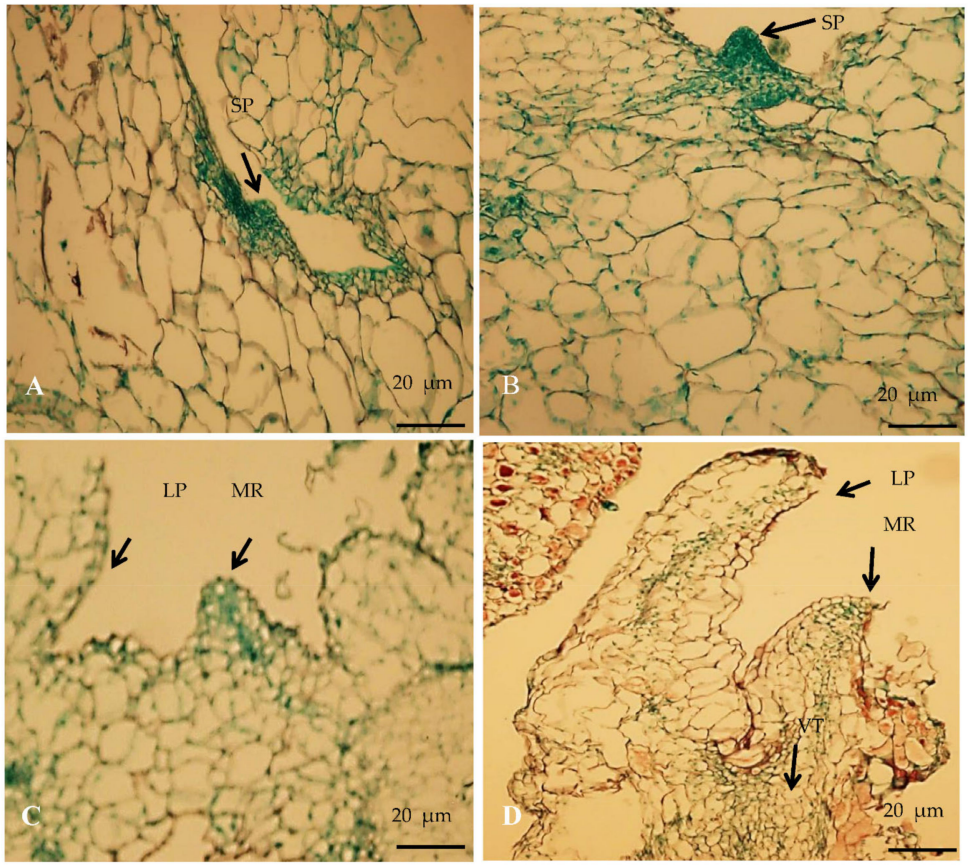

Figure 2. Histological analysis of the sequence of development of regenerated shoots from leaf explants of L. chinense cultured on MS supplemented with $0.5 \mathrm{mg} / \mathrm{L}$ TDZ. (A) Arrow head indicates the development of bud primordia from a meristematic dome after one week of culture (bar $=20 \mu \mathrm{m}$ ). (B) Development of shoot primordia (SP) from a leaf explant after two weeks of culture (bar $=20 \mu \mathrm{m})$. (C) Multiple regenerated shoots on the surface of a leaf explant after four weeks of culture (bar $=20 \mu \mathrm{m}$ ). (D) Longitudinal section of a bud connected to a leaf explant, showing the leaf primordia (LP), shoot apical meristem (MR), and vascular tissue (VT) after 24 days of culture (bar $=20 \mu \mathrm{m})$.
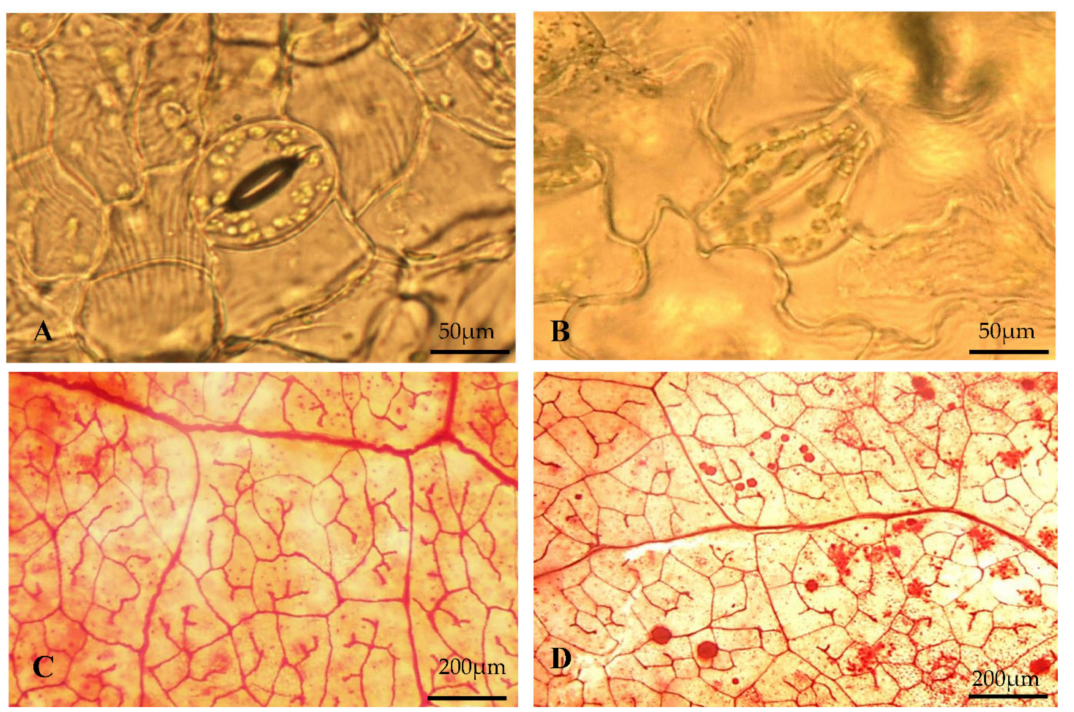

Figure 3. Foliar micromorphological studies of L. chinense. (A) Stomatal structure of regenerated plants (bar $=50 \mu \mathrm{m}),($ B $)$ mother plants (bar $=50 \mu \mathrm{m}),($ C) Venation pattern in leaves of in regenerated plants $($ bar $=200 \mu \mathrm{m})$, (D) mother plants $(\mathrm{bar}=200 \mu \mathrm{m})$.

Both regenerated and donor plants showed reticulate venation with profuse lateral branches. Vein-islet and veinlet terminations were distinct and similar (Figure 3C,D). The number of vein-islet terminations in regenerated plants was lower $(43.33 \pm 2.40)$ than in field-grown donor plants $(45.00 \pm 2.90)$ (Table 6$)$. 


\subsubsection{Trichome}

In the present study, dense trichomes were observed on the surface in leaves of regenerated and donor plants, and were unicellular and glandular (Figure 4A,B). Leaves from both regenerated and donor plants were morphologically similar in size (Figure $1 \mathrm{H}$ ). However, a significant variation was observed in terms of trichome density. In vitro plant leaves showed a higher number of trichomes $(25.00 \pm 1.74)$ than the donor plants (24.00 \pm 1.56$)$.
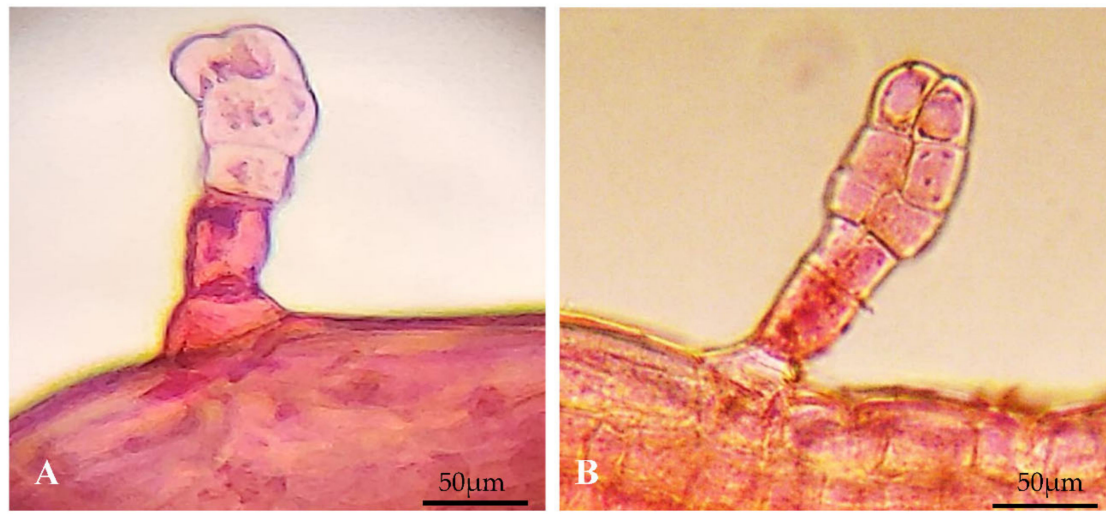

Figure 4. Microscopic structure of trichomes in the leaves of $(\mathbf{A})$ regenerated and $(\mathbf{B})$ mother plants $(\mathrm{bar}=50 \mu \mathrm{m})$.

\subsection{Assessment of Ploidy Levels of Regenerated Plants by Flow Cytometry}

Flow cytometry analyses were applied to study the ploidy levels of greenhouse-grown regenerated plants and donor plants (Figure $5 a, b)$. In the present study, similar peak fluorescence intensities were obtained for regenerated plants and donor plants. Moreover, all the plants regenerated via direct organogenesis showed the same ploidy levels as moth plants, as indicated by a single $2 \mathrm{C}$ peak. The results indicate a high level of genetic stability between the regenerated and donor plants without any somaclonal variations.

(a)

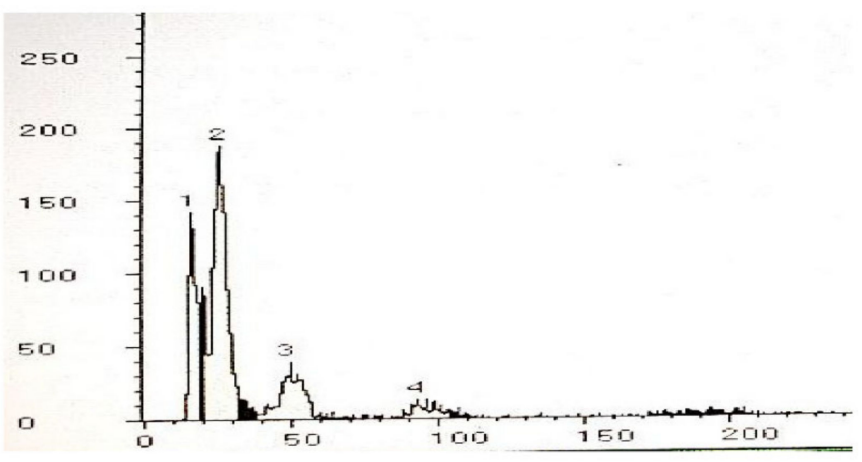

(b)

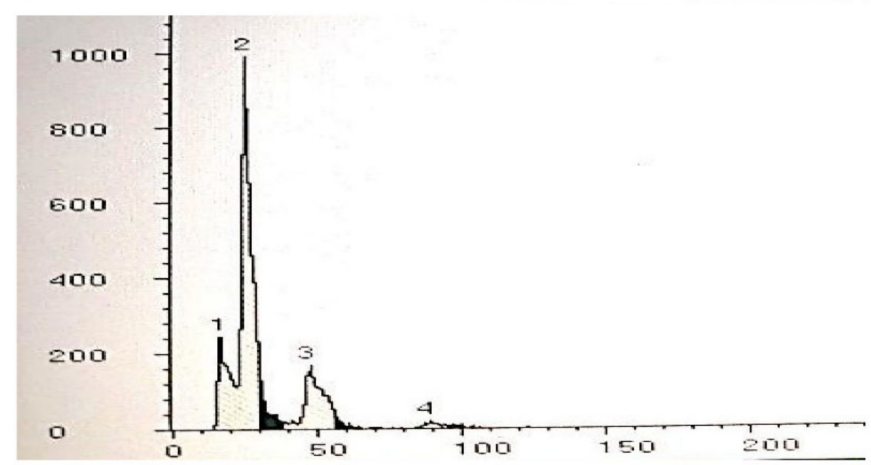

Figure 5. Flow cytometry analysis. (a) mother plant; (b) in vitro regenerated plants of L. chinense. 


\subsection{ISSR Analysis of Regenerated Plants}

To detect any genetic variability in the regeneration process, the regenerated and donor plants were evaluated for genetic stability by using ISSR markers (Figure 6). A total of ten ISSR primers used were identical and produced 110 scorable bands (Table 7), with an average of 10.5 bands per ISSR primer, ranging from 100 to $1000 \mathrm{bp}$. Bands were monomorphic in nature. The band patterns of in vitro regenerated plants and donor plants were similar in all aspects. No polymorphism was observed between the regenerated plants and the donor plants. The regenerated plants grown under greenhouse conditions and fields were free from any morphological variations. Similarity in the band pattern produced by ISSR primers confirmed the genetic stability and uniformity in regenerated and donor plants.

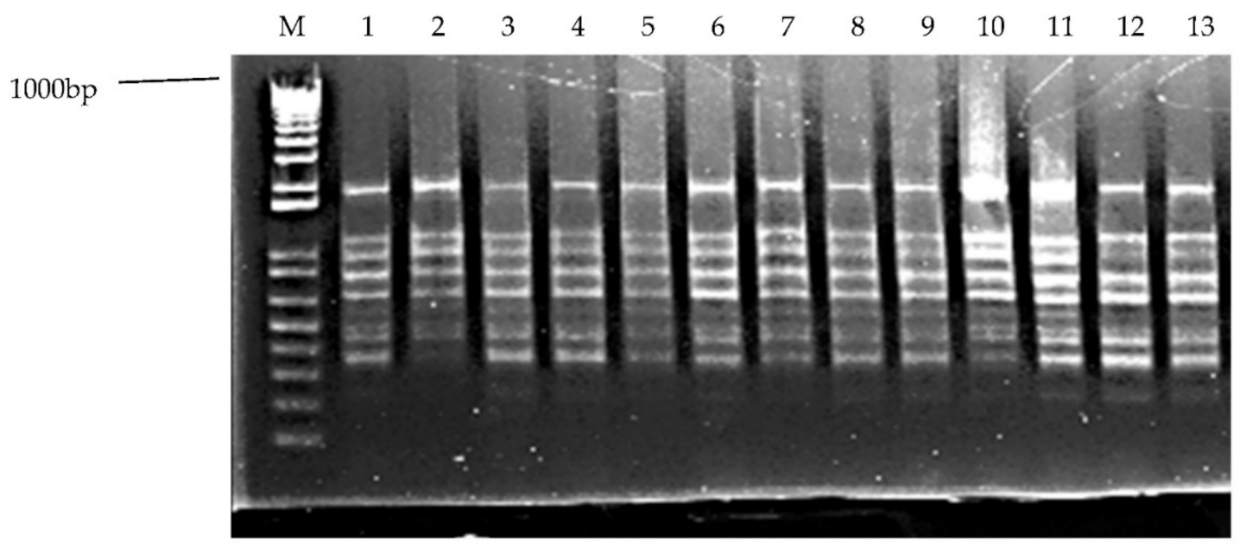

Figure 6. ISSR analysis of mother plant and in vitro regenerated plants of $L$. chinense. M- $1 \mathrm{~kb}$ DNA ladder, 1- mother plant, 2-13 in vitro regenerated plants. Amplification products obtained with inter simple sequence repeats primer (ISSR) using ISSR4 primer.

Table 7. Inter simple sequence repeat (ISSR) marker used for assessment of the genetic stability in regenerated shoots of L. chinense.

\begin{tabular}{cc}
\hline ISSR Primer & Base Sequence $\mathbf{( 5}^{\prime} \mathbf{- 3}^{\prime}$ ) \\
\hline ISSR1 & $(\mathrm{CTG})^{7} \mathrm{G}$ \\
ISSR2 & $(\mathrm{GAG})^{6} \mathrm{C}$ \\
ISSR3 & $(\mathrm{GAC})^{6} \mathrm{~T}$ \\
ISSR4 & $(\mathrm{GACA})^{5}$ \\
ISSR5 & $(\mathrm{GTC})^{6} \mathrm{~A}$ \\
ISSR6 & $(\mathrm{GTG})^{6} \mathrm{C}$ \\
ISSR7 & $(\mathrm{CTC})^{7}$ \\
ISSR8 & $(\mathrm{GTG})^{6} \mathrm{~A}$ \\
ISSR9 & $\mathrm{A}(\mathrm{CACA})^{3} \mathrm{CACTG}$ \\
\hline
\end{tabular}

\section{Discussion}

In the present study, the combination of various concentrations of auxins and cytokinins resulted in a low frequency of shoot regeneration. In contrast, the presence of lower concentrations of cytokinin $(0.5 \mathrm{mg} / \mathrm{L}$ BAP or $0.5 \mathrm{mg} / \mathrm{L}$ of TDZ) resulted in higher shoot regeneration. Further increase in the cytokinin concentration in the culture medium resulted in inhibition of shoot regeneration frequency. The results of the present study are in agreement with the report of Cappelletti et al. [37]. Adventitious shoot regeneration at lower concentrations of TDZ [37] and BAP [38] have been reported. Similarly, higher concentrations of auxins in the regeneration medium resulted in callus induction and inhibition of shoot formation. This result is consistent with the report of Bhagwat and Lane [39], where higher concentrations of auxins were not effective for inducing direct shoot regeneration in sweet cherry leaves. In the present study, the frequency of adventitious shoot 
regeneration was higher in the midrib sections than in other sections of the laminar region. The higher regeneration potential of the midrib region could be explained by the presence of higher percentages of vascular tissues [40]. In the present study, the presence of a lower concentration of TDZ $(0.5 \mathrm{mg} / \mathrm{mL})$ resulted in increased shoot induction. The positive influence of TDZ on adventitious shoot regeneration is in agreement with the results of Deore and Johnson [41], and Kumar et al. [42]. An earlier study reported that TDZ is involved in a number of metabolic processes including signal formation and its transport, and simultaneous stress response [43]. In another report, Zhang et al. [44] demonstrated the involvement of TDZ in ethylene production, an essential component of organogenesis. The higher efficiency of shoot regeneration by TDZ can also be attributed to the ability of this hormone to biosynthesize endogenous cytokinins [45], and as an effective bioregulator of morphogenesis [46]. In the present study, higher concentrations of TDZ resulted in reduced shoot regeneration, which can be explained by vetrification and cresting of the regenerating tissues at higher concentrations of TDZ [45]. Petiole explants showed higher regenerating potential than leaf explants, which could be due to higher meristematic activity in the basal region of the petiole [47]. Higher xylem and phloem tissues, and higher endogenous levels of hormones at the base of the petiolar region, midribs, and cut edges of leaves could be another reason for their higher shoot regenerating efficiency [48]. Histological analysis provided detailed information on shoot organogenesis, in which numerous meristemoids originated from the epidermal layers of leaf explants without callus formation. This observation was confirmed by the vascular connection between the regenerating shoots and mother explants.

The number and structure of stomata are responsible for major physiological and biochemical metabolism in plant cells [49]. A number of previous studies on plant regeneration systems have used stomatal characteristics to differentiate in vitro regenerated plants and donor plants [50-52]. A number of previous studies have revealed changes in the structure and density of stomata during shoot development in the acclimatization period of plantlets, and its transfer from in vitro to ex vitro conditions [53,54]. Moreover, differences in stomatal structure and density were observed between the in vitro and plant growth regulators conditions in Passiflora edulis [55], Oldenlandia coryonbosa [56], and Norinda coreia [57]. Some of the previous studies attributed these anomalies to low light intensity [58] and high hydration [59] in in vitro conditions.

The structure and density of trichomes are considered important biomarkers in plant identification [60]. These structures are responsible for secreting phytochemicals with curative properties and anti-herbivore activity [61]. These structures are more useful for protecting plant tissues against UV light [62], increasing tolerance to excessive heat and wind, and reducing water loss from the plant surface [57]. It has been reported that the frequency of foliar structures such as trichomes, stomata, and veinlets, changes when the plant is transferred to in vitro conditions to help the plant adapt to new conditions [63-65]. In this study, an increased number of trichomes was observed in the regenerated plant compared to the donor plants. It has been argued that PGRs present in the regeneration medium influence the development of trichomes in in vitro regenerating plants [66,67]. Recently, changes in the development of trichomes have been reported in other plant species $[65,68]$.

Venation pattern and vein-islet density of in vitro regenerated plants and donor plants grown in the field were analyzed. As shown in the results, highly compact and branched veinlets formed reticulate types of venation in both types of plants. The number of veinislets in regenerated plants was comparatively lesser than that in field-grown donor plants. This result also corroborates the study of Kull and Herbig [69], who observed a higher number of veinlet terminations in field-grown plants than in in vitro grown plants. In a similar study, Roth-Nibelsick et al. [70] attributed higher density of veinlets in field-grown plants to adopt plants under water stress conditions. Differences in the vein-islets in terms of their density in in vitro plants can be explained by the gradual development of vascular tissues in in vitro conditions $[65,68,71]$. 
The root grows rapidly and vigorously in media containing IAA and IBA. These auxins are helpful in initiating root organogenesis from the primordium, and the induction of lateral branches [72]. In the present study, IBA induced a higher number of roots and promoted root elongation. Higher root induction in the medium supplemented with IBA might be due to its organized acropetal movements and activation of genes required for rooting $[73,74]$. In the present study, half- strength MS basal salts and $3 \%$ sucrose in the rooting medium was effective in inducing the root. An increase in the optimal concentration or reduction in the salt and sugar in the rooting medium led to poor root formation. The effectiveness of root formation in reduced concentrations of basal salts has also been observed in previous studies performed with other plant species [75].

Flow cytometry is the most reliable and widely used method for estimating DNA content in plant tissues [76,77]. Application of PGRs and prolonged culture often causes variations in the DNA structure and chromosomal abnormalities that lead to morphological variations in the regenerated plants from its donor plants [78-81]. The results of flow cytometry analysis confirmed that all the regenerated shoots contained similar amounts of DNA as the donor plant, indicating the genetic stability of regenerated plants.

Genetic stability in regenerated plants is an important criterion during shoot induction [35]. Application of two types of molecular markers for the assessment of genetic stability in regenerated plants is a more reliable and useful technique [82,83]. In this report, the absence of polymorphic bands in the tested regenerated shoot indicates the genetic integrity and true-to-type nature compared with donor plants. Our results are in accordance with the results of Jin et al. [84] in Malus hupehensis, and Osena et al. [85] in Cassava, where ISSR molecular markers were used, and monomorphic bands were observed among the regenerated shoots via a direct regeneration process and strictly true-to donor plant type.

\section{Conclusions}

This study described a simple and efficient method of direct shoot regeneration of $L$. chinense, which is an important medicinal plant in Korea. The present study revealed a high percentage of shoot regeneration, successful acclimation, and genetical stability of regenerated plants. We believe that rapid shoot proliferation using leaf explants may serve as a valuable tool for mass propagation, ex situ conservation, and improvement of genetic traits in L. chinense.

Author Contributions: B.K.G. designed the experiment and wrote the manuscript. C.Y.Y. supervised the experiment. W.-S.J., S.-H.K., H.-Y.C. and I.-M.C. determined, analyzed the data, and edited the manuscript. All authors have read and agreed to the published version of the manuscript.

Funding: This manuscript received no external funding.

Institutional Review Board Statement: Not applicable.

Informed Consent Statement: Not applicable.

Data Availability Statement: Not applicable.

Acknowledgments: This study was supported by the KU Research Professor program. This work was supported by a BK21 FOUR (Fostering Outstanding Universities for Research, grant no. 4220201013822, team: Crop Genetic Resources Research Team for Future Human Resources Development in Sustainable Premium Agricultural Industry, Konkuk University) from the National Research Foundation of Korea, Republic of Korea.

Conflicts of Interest: The authors declare that they have no conflict of interest.

\section{References}

1. Hong, D.Y.; Pan, K.Y.; Nicholas, J.T. Flora of China; Science Press: Beijing, China, 2004; pp. 1-9.

2. Liu, S.C.; Lin, J.T.; Hu, C.C.; Shen, B.Y.; Chen, T.Y.; Chang, Y.L.; Shih, C.H.; Yang, D.J. Phenolic compositions and antioxidant attributes of leaves and stems from three inbred varieties of Lycium chinense Miller harvested at various times. Food Chem. 2017, 215, 284-291. [CrossRef]

3. Le, K.; Chiu, F.; Ng, K. Identification and Quantification of Antioxidants in Fructus lycii. Food Chem. 2007, 105, 353-363. [CrossRef] 
4. $\quad$ Kim, S.Y.; Lee, K.H.; Chang, K.S.; Bock, J.Y.; Jung, M.Y. Taste and flavor compounds in box thorn (Lycium chinense Miller) leaves. Food Chem. 1997, 58, 297-303. [CrossRef]

5. Lee, D.G.; Jung, H.J.; Woo, E.R. Antimicrobial property of (+)-lyoniresinol-3alpha-O-beta-D-glucopyranoside isolated from the root bark of Lycium chinense Miller against human pathogenic microorganisms. Arch. Pharm. Res. 2005, 28, 1031-1036. [CrossRef]

6. Wang, C.C.; Chang, S.C.; Inbaraj, B.S.; Chen, B.H. Isolation of carotenoids, flavonoids and polysaccharides from Lycium barbarum L. and evaluation of antioxidant activity. Food Chem. 2010, 120, 184-192. [CrossRef]

7. Zhang, Z.; Liu, X.; Wu, T.; Liu, J.; Zhang, X.; Yang, X.; Goodheart, M.J.; Engelhardt, J.F. Selective suppression of cervical cancer Hela cells by 2-O-b-D-glucopyranosyl-L-ascorbic acid isolated from the fruit of Lycium barbarum L. Cell Biol. Toxicol. 2011, 27, 107-121. [CrossRef] [PubMed]

8. Qian, J.; Liu, D.; Huang, A. The efficiency of flavonoids in polar extracts of Lycium chinense Mill. fruits as free radical scavenger. Food Chem. 2004, 87, 283-288. [CrossRef]

9. Noculak-Palczewska, A.; Matkowski, A.; Gasiorowski, K.; Tabaka, H.; Oszmianski, J.; Lamer-Zarawska, E. Chemical characterisation of methanolic-water extracts from the fruit of acclimated Lycium chinense Mill. Herba Pol. 2004, 50, 47-53.

10. Leung, I.; Tso, M.; Li, W.; Lam, T. Absorption and Tissue Distribution of Zeaxanthin and Lutein in Rhesus Monkeys after Taking Fructus lycii (Gou Qi Zi) Extract. Invest. Ophthalmol. Vis. Sci. 2001, 42, 466-471. [PubMed]

11. Kim, S.Y.; Choi, Y.H.; Huh, H.; Kim, J.; Kim, Y.C.; Lee, H.S. New antihepatotoxic cerebroside from Lycium chinense fruits. J. Nat. Prod. 1997, 60, 274-276. [CrossRef]

12. Noguchi, M.; Mochida, K.; Shingu, T.; Kozuka, M.; Fujitani, K. Uber die Bestandteile der chinesischen Droge “Ti-ku-'pi".I. isolierung und constitution von lyciumamid, einem neuen dipeptid. Chem. Pharm. Bull. 1984, 32, 3584-3587. [CrossRef] [PubMed]

13. Chin, Y.W.; Lim, S.W.; Kim, S.H.; Shin, D.Y.; Suh, Y.G.; Kim, Y.B.; Kim, Y.C.; Kim, J. Hepatoprotective pyrrole derivatives of Lycium chinense fruits. Bioorg. Med. Chem. Lett. 2003, 13, 79-81. [CrossRef]

14. Kim, J.S.; Chung, H.Y. GC-MS Analysis of the Volatile Components in Dried Boxthorn (Lycium chinenesis) Fruit. J. Korean Soc. Appl. Biol. Chem. 2009, 52, 516-524. [CrossRef]

15. Potterat, O. Goji (Lycium barbarum and L. chinense): Phytochemistry, Pharmacology, and Safety in the Per-spective of Traditional Uses and Recent Popularity. Planta Med. 2010, 76, 7-19. [CrossRef]

16. Tudor, V.; Asănică, A.; Teodorescu, I.R.; Gîdea, M.; Tănăsescu, C.; Tudor, A.D.; Tiu, V.J. Germination capacity of some Lycium barbarum L., and Lycium chinense Mill. biotypes seed. Rom. Biotechnol. Lett. 2017, 22, 12191-12196.

17. Kim, D.C.; Chung, H.J. Plant regeneration from explant types and cultivars of boxthorn (Lycium chinense Mill.). Korean J. Plant Biotechnol. 2002, 29, 15-18. [CrossRef]

18. Jo, M.H.; Ham, I.K.; Lee, B.C.; Kim, J.W.; Lee, W.S.; Kwon, S.Y.; Lee, H.S.; Kwak, S.S. High frequency shoot formation and plant regeneration from Cotyledonary hypocotyl explants of boxthorn (Lycium chinense Mill.) seedlings. Korean J. Plant Biotechnol. 2004, 31, 203-207.

19. Larkins, P.J.; Seowcroft, W.R. Somaclonal variation-A novel source of variability from cell cultures for plant improvement. Theor. Appl. Genet. 1981, 60, 197-214. [CrossRef] [PubMed]

20. Nyman, L.P.; Gonzales, C.J.; Arditti, J. In vitro selection for salt tolerance of taro (Colocasia esculenta vat. antiquorum). Ann. Bot. 1983, 51, 229-236. [CrossRef]

21. Rani, V.; Raina, S.N. Genetic fedility of organized meristem-derived micropropagated plants: A critical reappraisal. Vitr. Cell. Dev. Biol. Plant 1998, 36, 319-330. [CrossRef]

22. Dey, M.; Bakshi, S.; Galiba, G.; Sahoo, L.; Panda, S.K. Development of a genotype independent and transformation amenable regeneration system from shoot apex in rice (Oryza sativa spp. indica) using TDZ. 3 Biotech. 2012, 2, 233-240. [CrossRef]

23. Sticklen, M.B.; Oraby, H.F. Shoot apical meristem: A sustainable explant for genetic transformation of cereal crops. Vitr. Cell Dev. Biol. Plant 2005, 41, 187-200. [CrossRef]

24. Bramhanapalli, M.; Thogatabalija, L.; Gudipalli, P. Efficient in vitro plant regeneration from seedling-derived explants and genetic stability analysis of regenerated plants of Simarouba glauca DC. by RAPD and ISSR markers. Vitr. Cell Dev. Biol. Plant 2016, 53, 50-63. [CrossRef]

25. Romyanon, K.; Mosaleeyanon, K.; Kirdmanee, C. Direct-shoot organogenesis as an alternative protocol for in vitro regeneration of oil palm (Elaeis guineensis Jacq.). Sci. Hortic. 2015, 195, 1-7. [CrossRef]

26. Czene, S.; Harms-Ringdahl, M. Detection of single-strand breaks and formamidopyrimidine-DNA glycosylase-sensitive sites in DNA of cultured human fibroblasts. Mutat. Res. DNA Repair 1995, 336, 235-242. [CrossRef]

27. Ikeuchi, M.; Iwase, A.; Sugimoto, K. Control of plant cell diferentiation by histone modifcation and DNA methylation. Curr. Opin. Plant Biol. 2015, 28, 60-67. [CrossRef] [PubMed]

28. Lee, K.; Seo, P.J. Dynamic epigenetic changes during plant regeneration. Trends Plant Sci. 2018, 23, 235-247. [CrossRef]

29. Cui, C.; Li, Y.; Liu, Y.; Li, X.; Luo, S.; Zhang, Z.; Wu, R.; Liang, G.; Sun, J.; Peng, J.; et al. Determination of genetic diversity among Saccharina germplasm using ISSR and RAPD markers. C. R. Biol. 2017, 340, 76-86. [CrossRef]

30. Varshney, R.K.; Graner, A.; Sorrells, M.E. Genetic microsatellite markers in plants: Features and applications. Trends Biotechnol. 2005, 23, 48-55. [CrossRef]

31. Murashige, T.; Skoog, F. A revised medium for rapid growth and bioassays with tobacco tissue cultures. Physiol. Plant 1962, 15, 473-479. [CrossRef] 
32. Gamborg, L.; Miller, R.A.; Ojima, K. Nutrient requirements of suspension cultures of soybean root cells. Exp. Cell Res. 1968, 50, 151-158. [CrossRef]

33. Schenk, R.U.; Hildebrandt, A.C. Medium and techniques for induction and growth of monocotyledonous and dicotyledonous plant cell cultures. Can. J. Bot. 1972, 50, 199-204. [CrossRef]

34. Ghimire, B.K.; Seong, E.S.; Nguyen, T.X.; Yu, C.Y.; Kim, S.H.; Chung, I.M. In vitro regeneration of Melastoma malabatricum Linn. through organogenesis and assessment of clonal and biochemical fidelity using RAPD and HPLC. Plant Cell Tiss. Org. Cult. 2016, 124, 517-529. [CrossRef]

35. Ghimire, B.K.; Yu, C.Y.; Chung, I.M. Direct shoot organogenesis and assessment of genetic stability in regenerants of Solanum aculeatissimum Jacq. Plant Cell Tiss. Org. Cult. 2012, 108, 455-464. [CrossRef]

36. Doyle, J.J.; Doyle, J.L. Isolation of plant DNA from fresh tissue. Focus 1990, 12, 13.

37. Cappelletti, R.; Sabbadini, S.; Mezzetti, B. The use of TDZ for the efficient in vitro regeneration and organogenesis of strawberry and blueberry cultivars. Sci. Hortic. 2016, 207, 117-124. [CrossRef]

38. Gurel, E.; Topal, E.; Gurel, S. The effect of pretreating seedlings with BAP on direct shoot regeneration from periole explants of sugar beet (Beta vulgaris L.). Biotechnol. Biotechnol. Eq. 2003, 17, 89-96. [CrossRef]

39. Bhagwat, B.; Lane, W.D. In vitro shoot regeneration from leaves of sweet cherry (Prunus avium) 'Lapins' and 'Sweetheart'. Plant Cell Tiss. Org. Cult. 2004, 78, 173-181. [CrossRef]

40. Kumar, P.P.; Dimps Rao, C.; Goh, C.J. Influence of petiole and lamina on adventitious shoot initiation from leaf explants of Paulownia fortunei. Plant Cell Rep. 1998, 17, 886-890. [CrossRef]

41. Deore, A.C.; Johnson, T.S. High-frequency plant regeneration from leaf-disc cultures of Jatropha curcas L.: An important biodiesel plant. Plant Biotechnol. Rep. 2008, 2, 7-11. [CrossRef]

42. Kumar, N.; Vijay Anand, K.G.; Reddy, M.P. Shoot regeneration from cotyledonary leaf explants of Jatropha curcas a biodiesel plant. Acta Physiol. Plant 2010, 32, 917-924. [CrossRef]

43. Jones, M.P.A.; Cao, J.; O’Brien, R.; Murch, S.J.; Saxena, P.K. The mode of action of thidiazuron: Auxins, indoleamines, and ion channels in the regeneration of Echinacea purpurea L. Plant Cell Rep. 2007, 26, 1481-1490. [CrossRef]

44. Zhang, C.R.; Huang, X.L.; Wu, J.Y.; Feng, B.H.; Chen, Y.F. Identification of thidiazuron-induced ESTs expressed differentially during callus differentiation of alfalfa (Medicago sativa). Physiol. Plant 2006, 128, 732-739. [CrossRef]

45. Huetteman, C.A.; Preece, J.E. Thidiazuron: A potent cytokinin for woody plant tissue culture. Plant Cell Tiss. Org. Cult. 1993, 33, 105-119. [CrossRef]

46. Murthy, B.N.S.; Murch, S.J.; Saxena, P.K. Thidiazuron: A potent regulator of in vitro plant morphogenesis. Vitr. Cell Dev. Biol. Plant 1998, 34, 267-275. [CrossRef]

47. Ghimire, B.K.; Seong, E.S.; Goh, E.J.; Kim, N.Y.; Kang, W.H.; Kim, E.H.; Yu, C.Y.; Chung, I.M. High-frequency direct shoot regeneration from Drymaria cordata Willd. leaves. Plant Cell Tiss. Org. Cult. 2010, 100, 209-217. [CrossRef]

48. Karam, N.S.; Al-Majathoub, M. Direct shoot regeneration and microtuberization in wild Cyclamen persicum Mill. using seedling tissue. Sci. Hort. 2000, 86, 235-246. [CrossRef]

49. Ďurkovič, J.; Alžbeta Lengyelová, A.; Ingrid Čaňová, I.; Daniel Kurjak, D.; Hladka, D. Photosynthetic performance and stomatal characteristics during ex vitro acclimatization of true service tree (Sorbus domestica L.). J. Hort. Sci. Biotechnol. 2009, 84, $223-227$. [CrossRef]

50. Mani, M.; Shekhawat, M.S. Foliar micromorphology of in vitro-cultured shoots and field-grown plants of Passiflora foetida. Hortic. Plant J. 2017, 3, 34-40. [CrossRef]

51. Carvalho Luisa, C.; Leonor Osório, M.; Manuela Chaves, M.; Amâncio, S. Chlorophyll fluorescence as an indicator of photosynthetic functioning of in vitro grapevine and chestnut plantlets under ex vitro acclimatization. Plant Cell Tiss. Org. Cult. 2001, 67, 271-280. [CrossRef]

52. Revathi, J.; Manokari, M.; Shekhawat, M.S. Optimization of factors affecting in vitro regeneration, flowering, ex vitro rooting and foliar micromorphological studies of Oldenlandia corymbosa L.: A multipotent herb. Plant Cell Tiss. Org. Cult. 2018, 134, 1-13. [CrossRef]

53. Kozai, T.; Iwabuchi, K.; Watanabe, K.; Watanabe, I. Photoautotrophic and photomixotrophic growth of strawberry plantlets in vitro and changes in nutrient composition of the medium. Plant Cell Tiss. Org. Cult. 1991, 25, 107-115.

54. Gaspar, T.; Franck, T.; Bisbis, B.; Kevers, C.; Jouve, L.; Hausman, J.F.; Dommes, J. Concepts in plant stress physiology. Application to plant tissue cultures. Plant Growth Regul. 2002, 37, 263-285. [CrossRef]

55. Manokari, M.; Shekhawat, M.S. Comprehensive analysis of in vitro to feld transition of micromorphology and leaf architecture in Passiflora edulis Sims. f. flavicarpa Deg. Ind. J. Plant Physiol. 2017, 22, 240-246. [CrossRef]

56. Wang, F.; Xin, X.; Wei, H.; Qiu, X.; Liu, B. In vitro regeneration, ex vitro rooting and foliar stoma studies of Pseudostellaria heterophylla (Miq.) Pax. Agronomy 2020, 10, 949. [CrossRef]

57. Shekhawat Mahipal, S.; Manokari, M.; Kannan, N. Micromorphological response towards altered environmental conditions in subsequent stages of in vitro propagation of Morinda coreia. Environ. Exp. Biol. 2017, 15, 37-46.

58. Saez, P.L.; Bravo, L.A.; Latsagne, M.I.; Rios, D.G. Increased light intensity during in vitro culture improves water loss control and photosynthetic performance of Castanea sativa grown in ventilated vessels. Sci. Hortic. 2012, 138, 7-16. [CrossRef] 
59. Machado, M.P.; Silva, A.L.L.; Biasi, L.A.; Deschamps, C.; Filho, J.C.B.; Zanette, F. Influence of calcium content of tissue on hyperhydricity and shoot tip necrosis of in vitro regenerated shoots of Lavandula angustifolia Mill. Braz. Arch. Biol. Technol. 2014, 57, 636-643. [CrossRef]

60. Spring, O. Chemotoxonomy based on metabolites from glandular trichomes. Adv. Bot. Res. 2000, 31, 153-174.

61. Naidoo, G.; Kaliamoorthy, S.; Naidoo, Y. The secretory apparatus of Xerophyta viscosa (Velloziaceaea): Epidermis anatomy and chemical composition of the secretory product. Flora 2009, 204, 561-568. [CrossRef]

62. Manetas, Y. The importance of being hairy: The adverse effects of hair removal on stem photosynthesis of Verbascum speciosum are due to solar UV-B radiation. New Phytol. 2003, 158, 503-508. [CrossRef]

63. Yang, F.; Miao, L.F. Adaptive responses to progressive drought stress in two poplar species originating from different altitudes Silva Fenn. 2010, 44, 23-37. [CrossRef]

64. Osório, M.L.; Gonçalves, S.; Coelho, N.; Osório, J.; Romano, A. Morphological, physiological and oxidative stress markers during acclimatization and field transfer of micropropagated Tuberaria major plants. Plant Cell Tiss. Org. Cult. 2013, 115, 85-97. [CrossRef]

65. Lodha, D.; Patel, A.K.; Shekhawat, N.S. A high frequency in vitro multiplication, morphological studies and ex vitro rooting of Cadaba fruticose (L.) Druce (Bahuguni): A multipurpose endangered medicinal shrub. Physiol. Mol. Biol. Plants 2015, 21, 407-415. [CrossRef]

66. Traw, M.B.; Bergelson, J. Interactive effects of jasmonic acid, salicylic acid, and gibberellin on induction of trichomes in Arabidopsis. Plant Physiol. 2003, 133, 1367-1375. [CrossRef]

67. Kim, T.D.; Lee, B.S.; Kim, T.S.; Choi, Y.E. Developmental plasticity of glandular trichomes into somatic embryogenesis in Tilia Amurensis. Ann. Bot. 2007, 100, 177-183. [CrossRef] [PubMed]

68. Shekhawat, M.S.; Manokari, M. vitro propagation, micromorphological studies and ex vitro rooting of cannon ball tree (Couroupita guianensis Aubl.): A multipurpose threatened species. Physiol. Mol. Biol. Plants 2016, 22, 131-142. [CrossRef] [PubMed]

69. Kull, U.; Herbig, A. Das Blattadersystem der Angiospermen: Form und Evolution. Naturwissenschaften 1995, 82, 441-451. [CrossRef]

70. Roth-Nebelsick, A.; Uhl, D.; Mosbrugger, V.; Kerp, H. Evolution and function of leaf venation architecture: A review. Ann. Bot. 2001, 87, 553-566. [CrossRef]

71. Rathore, M.S.; Rathore, M.S.; Shekhawat, N.S. Ex vivo implications of phyto-hormones on various in vitro responses in Leptadenia reticulata (Retz.) Wight \& Arn-An endangered plant. Environ. Exp. Bot. 2013, 86, 86-93.

72. Fukaki, H.; Tasaka, M. Hormone interactions during lateral root formation. Plant Mol. Biol. 2009, 69, 437-449. [CrossRef] [PubMed]

73. Rufai, S.; Hanafi, M.M.; Rafii, M.Y.; Mohidin, H.; Omar, S.R.S. Growth and development of Moringa (Moringa oleifera L.) stem cuttings as affected by diameter magnitude, growth media and indole-3-butyric acid. Ann. Res. 2016, 59, 209-218. [CrossRef]

74. Sharma, U.; Kataria, V.; Shekhawat, N.S. vitro propagation, ex vitro rooting and leaf micromorphology of Bauhinia racemosa lam.: A leguminous tree with medicinal values. Physiol. Mol. Biol. Plants 2017, 23, 969-977. [CrossRef]

75. Purohit, S.D.; Singhvi, A. Micropropagation of Achras sapota through enhanced axillary branching. Sci. Hort. 1998, 76, 219-229. [CrossRef]

76. Ochatt, S.J.; Mousset-Déclas, C.; Rancillac, M. Fertile pea plants regenerate from protoplasts when calluses have not undergone endoreduplication. Plant Sci. 2000, 156, 177-183. [CrossRef]

77. Nassour, M.; Chassériaux, G.; Dorion, N. Optimization of protoplast-to-plant system for Pelargonium $\times$ hortorum 'Alain' and genetic stability of the regenerated plants. Plant Sci. 2003, 165, 121-128. [CrossRef]

78. LoSchiavo, F.; Pitto, L.; Giuliano, G.G.; Torti, V.; Nuti-Ronchi, D.; Marazziti, R.; Vergara, S.; Orselli, M.T. DNA methylation of embryogenic carrot cell cultures and its variations as caused by mutation, differentiation, hormones and hypomethylating drugs. Theor. Appl. Genet. 1989, 77, 325-331. [CrossRef]

79. Leljak-Levanić, D.; Bauer, N.; Mihaljević, S.; Jelaska, S. Changes in DNA methylation during somatic embryogenesis in Cucurbita pepo L. Plant Cell Rep. 2004, 23, 120-127. [CrossRef]

80. Fraga, H.P.F.; Vieira, L.N.; Caprestano, C.A.; Steinmacher, D.A.; Micke, G.A.; Spudeit, D.A.; Pescador, R.; Guerra, M.P. 5Azacytidine combined with 2,4-D improves somatic embryogenesis of Acca sellowiana (O. Berg) Burret by means of changes in global DNA methylation levels. Plant Cell Rep. 2012, 31, 2165-2176. [CrossRef]

81. Fehér, A.; Pasternak, T.; Dudits, D. Transition of somatic plant cells to an embryogenic state. Plant Cell Tiss. Org. Cult. 2003, 74, 201-228. [CrossRef]

82. Martin, K.P.; Pachathundikandi, S.; Zhang, C.L.; Slater, A.; Madassery, J. RAPD analysis of a variant of banana (Musa sp.) cv. grandenaine and its propagation via shoot tip culture. Vitr. Cell Dev. Biol. Plant 2006, 42, 188-192. [CrossRef]

83. Venkatachalam, L.; Sreedhar, R.V.; Bhagyalakshmi, N. Molecular analysis of genetic stability in long-term micropropagated shoots of banana using RAPD and ISSR markers. Elect. J. Biotech. 2007, 15, 106-113.

84. Jin, W.; Wang, Y.; Wang, H. Adventitious shoot regeneration from leaves of apple rootstock 'Pingyitiancha' (Malus hupehensis var. pinyiensis) and genetic fidelity of regenerated plantlets using SSR markers. Can. J. Plant Sci. 2014, 94, 1345-1354. [CrossRef]

85. Osena, G.; Amugune, N.O.; Nyaboga, E.N. Genetic stability of Cassava plants regenerated through organogenesis using microsatellite markers. J. Plant Sci. 2017, 5, 19-28. 